\title{
How accurate is the local ecological knowledge of protected area practitioners?
}

\author{
Carly N. Cook $^{1,2}$, Grant Wardell-Johnson $^{3},{\underline{\text { R. W. } \text { Carter }^{4}}}^{4}$ and Marc Hockings $^{2}$
}

\begin{abstract}
The scarcity of environmental data means that other sources of information are needed to complement empirical evidence for conservation decisions. By regularly interacting with their local environment, protected area practitioners may generate local ecological knowledge (LEK) that can be used to inform management decisions. However, the accuracy of LEK is generally poorly understood, and no studies have assessed the accuracy of practitioners' personal knowledge, leading to a vital gap in our ability to best use this information to guide management. We measured the accuracy of practitioners' knowledge of the vegetation condition within protected areas, relative to an empirical vegetation condition assessment tool. Despite the vast majority of practitioners having only personal experiences to inform their judgments, we found that almost $60 \%$ of practitioners made assessments of vegetation condition that matched the empirical condition estimates. When inaccurate, practitioners tended to be conservative in their estimates of condition. Although underestimating condition in this way may waste resources through unnecessary management actions, this is likely to be preferable to overestimating condition and thus failing to protect biodiversity by prematurely ceasing restoration programs. We found no relationship between the accuracy of practitioners' LEK and their level of experience as a practitioner, their level of education, or their gender. We believe that under many circumstances practitioners can be a valuable and cost-effective source of information about the condition of the protected areas they manage, but that more research is needed to understand the wide range of factors that may contribute to how land managers build LEK and how management agencies can assist practitioners to build a good understanding of the conditions in their reserves.
\end{abstract}

Key Words: conservation decisions; environmental management; evaluation; local ecological knowledge; vegetation condition

\section{INTRODUCTION}

The shortage of empirical data available to inform decisions about protected area management means that other sources of information must be sought to inform management decisions (Cook et al. 2012). The most common source of information about the condition of protected areas is the personal experience of "on-ground" managers, i.e., those individuals responsible for the day-to-day management decisions and activities within a protected area, hereafter called practitioners (Sutherland et al. 2004, Cook et al. 2010a, Cook and Hockings 2011). Increasingly, personal knowledge in the form of expert opinion (Kuhnert et al. 2010, Martin et al. 2012) or local ecological knowledge (LEK; Gilchrist et al. 2005, Brook and McLachlan 2008, Anadón et al. 2009 ) is being viewed as a valuable source of information for ecology and conservation. Information derived from personal judgments is an attractive complement to, or substitute for, empirical data because it is often readily available and relatively cost-effective to collect (Lele and Allen 2006). Therefore, relying on the personal knowledge of protected area practitioners is an attractive solution to the data shortages experienced by management agencies. However, it is unclear how confident we can be in the accuracy of practitioners' knowledge as a source of evidence to guide protected area management.

We consider practitioners' knowledge within the conceptual framework of LEK rather than expert opinion because LEK requires no formal training but is generally thought to be derived from the direct experiences of people within natural environments, often making their livelihoods from the environments, such as farmers, hunters, fishers, and recreationalists (Brook and McLachlan 2008). Conversely, experts are individuals with formal qualifications, a track record, and professional standing (Burgman et al. 2011), which would preclude most on-ground practitioners from being considered the holders of expert knowledge. On-ground practitioners have direct experience with their local natural environment and manipulate it through management actions, often using the observed outcomes to adapt management strategies in the manner of farmers, fishers, and hunters. Practitioners also have access to a range of information about their reserves (Cook et al. 2012) that they can use to help build their knowledge of the local environment. Management experience is considered important in building an understanding of the important factors that influence the effectiveness of management interventions (Woodwell 1989, Fazey et al. 2005), yet we know of no examples in which on-ground practitioners of protected areas have been considered as a source of LEK.

The term LEK has been used in different ways, including to encompass all forms of local knowledge, including traditional ecological knowledge (TEK) and indigenous ecological knowledge (IEK; Brook and McLachlan 2008). We use the definition of LEK that places emphasis on practical skills (Berkes 1999), developed at a local scale (McGregor 2000) through direct experience (Davis and Ruddle 2010), and can incorporate relevant technical and scientific information when it is available (Agrawal 1995). In this way, it is distinguished from definitions of TEK or IEK that are generally considered to require a body of knowledge that is accumulated and passed down over generations (Gadgil et al. 1993, Berkes et al. 2000). Not all scholars consider intergenerational knowledge transfer to be essential for the formation of IEK but suggest that all ecological knowledge is generated through experience (Lauer and Aswani 2009). The type of experience gained by practitioners through their interactions 
with the environment in their daily activities provides a strong foundation for building LEK.

LEK is considered particularly useful for environmental management decisions (Huntington 2000, Brook and McLachlan 2008, Anadón et al. 2009, Davis and Ruddle 2010) and has been used to provide information about the presence or abundance of species (Leedy 1949, Vaughan et al. 2003, Moller et al. 2004, Anadón et al. 2009), population trends (Gilchrist et al. 2005, Lozano-Montes et al. 2008), and size-class distributions (Aswani and Hamilton 2004). It has been shown to be a cost-effective source of ecological data (e.g., Gilchrist et al. 2005, Anadón et al. 2009), particularly when conventional ecological research is too expensive or cannot be conducted within the necessary time frame (Stave et al. 2007). Therefore, the LEK of on-ground practitioners may provide a rich and readily available source of information for protected area management agencies to supplement existing data. Given the shortage of scientific information in protected areas (Sutherland et al. 2004, Cook et al. 2010a), the experience of practitioners could be an important substitute for, or complement to, empirical scientific data to guide management decisions.

Although readily available, information derived from personal experience can be susceptible to a range of biases (Plous 1993). If biases distort practitioners perceptions of on-ground conditions, they could lead to poor conservation outcomes (Sutherland 2006). Therefore, it is important to understand the accuracy of personal assessments (Burgman 2001, Gilchrist et al. 2005) before they are used to guide management practices. Although practitioners could provide a rich and readily available source of LEK to supplement existing data, it is important to understand how this information compares with more traditional sources of evidence, such as empirical scientific data, before it can be confidently used to guide management practices. Despite the importance of LEK to conservation management (Huntington 2000, Brook and McLachlan 2008, Anadón et al. 2009), its accuracy is rarely tested (Davis and Ruddle 2010). The few studies to test the accuracy of LEK held by traditional owners and farmers relative to empirical scientific data have concluded that it can provide an important source of evidence (Aswani and Hamilton 2004, Aswani and Lauer 2006, Hernandez-Stefanoni et al. 2006, Lauer and Aswani 2008, Anadón et al. 2009) but can also have limitations (Aswani and Hamilton 2004, Gilchrist et al. 2005). Although the knowledge of practitioners is widely used and has the potential to significantly influence management outcomes, we know of no studies to test the accuracy of practitioners' judgments about the conditions in their reserves.

We measured how practitioners' knowledge about the condition of their protected areas compares with empirical estimates of condition generated through a field-based condition assessment tool, considered by many to be the most desirable source of evidence to inform management decisions (Gibbons and Freudenberger 2006). We determined how the comparability of practitioners' knowledge to empirical scientific assessment varied with the following: (1) the type of the evidence practitioners had available to inform their judgments, (2) their level of experience, and (3) their level of education. We discuss our results in relation to the confidence that should be placed in the LEK of practitioners relative to empirical scientific estimates and how protected area management agencies might promote practitioners building a strong understanding of their local environment.

\section{METHODS}

We focused on vegetation condition as the ecological attribute to be assessed by practitioners because it is considered an important indicator of the success of management actions and can be used to monitor change over time and to prescribe restoration treatments (Gibbons and Freudenberger 2006). Given the importance to management decisions of understanding vegetation condition, it would be valuable if this attribute could be assessed on the basis of the LEK generated through day-today management within protected areas. In contrast to the costs of collecting empirical estimates of vegetation condition, LEK has the advantage of being relatively cheap and readily available. However, vegetation condition can be a complex concept (Keith and Gorrod 2006) that is challenging to objectively assess and to judge visually (Cook et al. 2010b). Biodiversity conservation is the primary goal of protected area management; therefore, we adopt the definition of vegetation condition used by Keith and Gorrod (2006) as it relates to biodiversity: the capacity of vegetation to sustain local populations of plants and animals, their genetic diversity, and ecological interactions.

Our case study focused on protected area practitioners working for the New South Wales Office of Environment and Heritage (NSW OEH) in Australia, a state-level government agency charged with protecting biodiversity and cultural heritage, as well as facilitating and managing recreational visitors. The NSW OEH is responsible for more than 800 protected areas in the state of NSW, totaling more than 7 million ha, i.e., $9 \%$ of the state. We targeted the views of on-ground practitioners, who are responsible for day-to-day decisions about protected area management, e.g., what threats to manage within a protected area, where to focus management activities, and which management actions are most appropriate.

\section{Identifying key informants}

It is accepted that not all individuals who potentially qualify as holders of LEK are similar in the substance and character of their knowledge (Davis and Wagner 2003, Lauer and Aswani 2009). Likewise, personal attributes can influence the reliability of LEK, so it is considered important to select a relatively homogenous group (Anadón et al. 2009). Therefore, we limited our sample to on-ground practitioners. These are the practitioners who spend the most time out in the reserves, addressing a wide range of management issues, and who are most familiar with on-ground conditions. We targeted practitioners who manage nature reserves because these reserves are primarily designated for nature conservation (IUCN 1994) and practitioners are focused on management issues relevant to biodiversity conservation. We also limited our sample to reserves of $<10,000$ hectares $(n=358)$ in an attempt to standardize the likelihood that practitioners can regularly access, and are therefore familiar with, the majority of the protected area. Smaller nature reserves of this kind are only managed by one practitioner, making them the key informant, whereas larger reserves are often managed by a team of practitioners who share knowledge about the reserve. We restricted our sample to protected areas where vegetation was 
identified as an important conservation value to ensure that practitioners would be considering vegetation condition as part of their management strategy $(n=242)$.

Although management experience is likely to form a large part of a practitioners' knowledge, LEK can also include relevant scientific information (Agrawal 1995). We were interested in whether practitioners had integrated the available empirical evidence with their personal experience. Therefore, we stratified our sample according to those practitioners who reported that they had empirical condition information to support their assessments and those who formed their judgment based on personal experience alone. We ensured that none of the practitioners who reported having empirical condition information for their protected areas had used the same rapid assessment method as our empirical estimate of condition, i.e., the BioMetric method. We selected a total of 28 practitioners: 16 with empirical data and experience, and 12 with experience alone.

The 28 practitioners in our sample represented 28 separate protected areas from across NSW. Most of the practitioners in our sample were male $(n=18)$ rather than female $(n=10)$, which reflects the gender imbalance of on-ground managers within the agency. Although we did not limit our sample to nonindigenous staff members, none of the practitioners in our sample were of Aboriginal descent.

The nature reserves in our sample were located in a mixture of urban $(\mathrm{n}=5)$ and rural $(\mathrm{n}=23)$ areas, representing both inland $(n=23)$ and coastal $(n=5)$ environments. All of the reserves had a history of disturbance by timber harvesting $(n=16)$, livestock grazing $(n=15)$, inappropriate management of fire $(n=4)$ or water regimes $(n=3)$, mining $(n=3)$, pollution $(n=2)$, and/or land clearing $(\mathrm{n}=1$; Appendix 1$)$.

\section{Documenting practitioners' local ecological knowledge}

Although documenting LEK through detailed interviews can provide a rich source of information (Aswani and Hamilton 2004), we chose to use questionnaires to document the knowledge of practitioners because they provide a simple way to compare responses and are considered particularly useful when the researcher knows in advance the information they are seeking (Huntington 2000). The questionnaire e-mailed to practitioners asked them to rate the condition of one vegetation community according to a set of four criteria (Table 1) developed by the protected area management agency to rank condition (Hockings et al. 2009). These criteria represent an ordinal measure of condition, and as with the empirical condition assessment tool, they are designed to assess the structure, function, and composition of the vegetation (DEC 2006). Maps can be useful when documenting LEK (Huntington 2000), and we provided practitioners with a map of their protected area that highlighted the location of the vegetation community to be assessed. This was to ensure that practitioners were assessing the patch of vegetation where the empirical estimates were made. There was variability in the type, size $(\mu=714 \pm 167 \mathrm{ha})$, and heterogeneity of the different vegetation communities assessed by the practitioners. However, this variation reflects the range of variability that practitioners are likely to experience when judging vegetation condition in their protected areas. Practitioners were asked to provide estimates of average condition across the vegetation community and to note whether their estimates were based solely on their personal perceptions and experience, i.e., experience alone, or whether they had any empirical data available, i.e., experience and data.

Table 1. The assessment criteria against which protected area practitioners were asked to assess the condition of vegetation.

\begin{tabular}{lc}
\hline \hline Assessment criteria & Score \\
\hline $\begin{array}{l}\text { The components of the vegetation community } \\
\text { (structure, function, and composition) are not }\end{array}$ & 4 \\
degraded. & \\
$\begin{array}{l}\text { Some components of the vegetation community } \\
\text { (structure, function, and composition) are degraded }\end{array}$ & 3 \\
but not currently at risk. & \\
$\begin{array}{l}\text { Some components of the vegetation community } \\
\text { (structure, function, and composition) are degraded }\end{array}$ & \\
and are at risk without corrective action. & \\
The components of the vegetation community & 1 \\
(structure, function, and composition) are degraded & \\
and are at continuing risk without corrective action. &
\end{tabular}

The amount of experience an individual has with his or her environment is likely to influence the quality and depth of knowledge (Anadón et al. 2009). To determine whether the level of experience of practitioners contributes to the reliability of their local knowledge, we used the number of years of experience each practitioner had with the protected area being sampled (Cook 2010). However, we also considered the total number of years of experience a practitioner had across their career, given that a diversity of experience could be important to help practitioners judge relative condition and to learn to recognize environmental cues. The total number of years of management experience is also likely to be a good surrogate for the age of a practitioner. We also asked practitioners to indicate their highest level of education.

\section{Rapid condition assessment}

We used the "site value" component of the "BioMetric" index developed for the NSW OEH in Australia as the rapid assessment tool to empirically measure vegetation condition. The BioMetric tool was developed to help the agency determine the impacts of proposed land clearing on terrestrial biodiversity, and it includes a site value component to measure vegetation condition for all vegetation types in NSW (Gibbons et al. 2009). The rapid condition assessment is based on 10 attributes (Table 2) that represent the structure, function, and composition of the vegetation (Gibbons et al. 2009). We then excluded the constants, multipliers, and weightings used to calculate the metric, so that the site value assessment would represent current condition, rather than the impacts of habitat loss (S. Briggs, NSW OEH, personal communication). This modified metric is described in Gibbons et al. (2009) as follows:

$$
\text { Current vegetation condition }=\frac{\left(\sum_{v=a}^{g} s_{\mathrm{v}}\right)+k}{c}
$$

where $s_{\mathrm{v}}$ is the score for the $v$ th condition attribute $(a-g)$ as defined in Table $2, k=\left(s_{\mathrm{h}}+s_{\mathrm{i}}+s_{\mathrm{j}}\right) / 3$, and $c$ is the maximum score that 
Table 2. The condition attributes measured using the site value component of the BioMetric tool (Gibbons et al. 2005).

\begin{tabular}{|c|c|c|}
\hline Attribute & Sampling approach & Description of method \\
\hline $\begin{array}{l}\text { Indigenous plant species } \\
\text { richness }\end{array}$ & $20 \times 20 \mathrm{~m}$ plot & Count of all indigenous species (vascular plants) \\
\hline Native overstorey cover & $\begin{array}{l}10 \text { points along a } 50 \mathrm{~m} \\
\text { transect }\end{array}$ & $\begin{array}{l}\text { Every } 5 \mathrm{~m} \text { the percent cover of woody species directly overhead was } \\
\text { visually estimated and averaged for the transect. }\end{array}$ \\
\hline Native midstorey cover & $\begin{array}{l}10 \text { points along a } 50 \mathrm{~m} \\
\text { transect }\end{array}$ & $\begin{array}{l}\text { Every } 5 \mathrm{~m} \text { the percent cover of species between the overstorey and } 1 \mathrm{~m} \\
\text { were visually estimated and averaged for the transect. }\end{array}$ \\
\hline $\begin{array}{l}\text { Native ground cover } \\
\text { (grasses, shrubs, and other) }\end{array}$ & $\begin{array}{l}50 \text { points along a } 50 \mathrm{~m} \\
\text { transect }\end{array}$ & $\begin{array}{l}\text { Every } 1 \mathrm{~m} \text { the percentage cover was recorded and averaged for the } \\
\text { transect. Ground cover estimates were made separately for grass, shrub, } \\
\text { and other species then averaged for the quadrat. }\end{array}$ \\
\hline Exotic plant cover & $\begin{array}{l}50 \text { points along a } 50 \mathrm{~m} \\
\text { transect }\end{array}$ & $\begin{array}{l}\text { Every } 1 \mathrm{~m} \text { the percentage cover of exotic species (at all strata) was } \\
\text { recorded and averaged for the transect. }\end{array}$ \\
\hline $\begin{array}{l}\text { Number of trees with } \\
\text { hollows }\end{array}$ & $50 \mathrm{~m} \times 20 \mathrm{~m}$ plot & $\begin{array}{l}\text { Count of all trees (living or dead) with at least one hollow and the } \\
\text { number of trees per hectare calculated. }\end{array}$ \\
\hline Regeneration & $50 \times 20 \mathrm{~m}$ plot & Proportion of overstorey tree species regenerating \\
\hline Total length of fallen logs & $50 \times 20 \mathrm{~m}$ plot & Total length of $\operatorname{logs}>10 \mathrm{~cm}$ in diameter and at least $0.5 \mathrm{~m}$ long. \\
\hline
\end{tabular}

can be obtained given the attributes that occur in the benchmark for the vegetation type. Following the method detailed in Gibbons et al. (2005), we used nested $20 \times 20 \mathrm{~m}$ and $20 \times 50 \mathrm{~m}$ quadrats, bisected by a $50-\mathrm{m}$ transect (Fig. 1), to measure the condition parameters (Table 2). Field data were compared with benchmark values developed for the corresponding broad vegetation type (see Gibbons et al. 2009). The benchmarks represent estimates of the vegetation condition prior to modification since European settlement. This was based on a combination of existing data sets, expert opinion (Gibbons et al. 2005), and empirical measurements (Gibbons et al. 2008). Each attribute score is ranked on a 4-point, ordinal scale (1-4) according to its relationship to the benchmark value for the vegetation type (Gibbons et al. 2009).

Fig. 1. Configuration used for data collection. Nested $20 \times 20 \mathrm{~m}$ (grey) and $50 \times 20 \mathrm{~m}$ (black and grey) quadrats and a $50 \mathrm{~m}$ line transect (white). Adapted from (Gibbons et al. 2005).

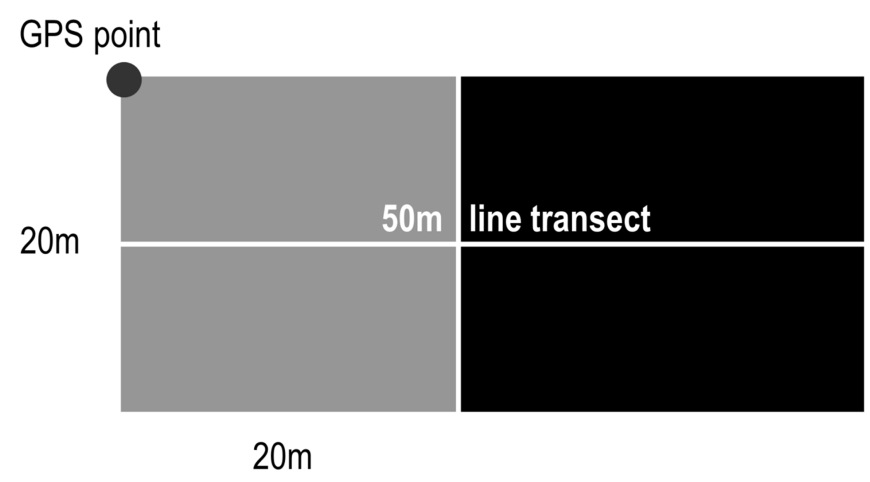

The vegetation communities sampled (Appendix 1) were selected because they were listed as a management priority in planning documents for the protected area. Where no management priorities were listed, the most extensive vegetation community in the protected area was used. Although the vegetation communities varied between the protected areas sampled, we found no effect of the broad vegetation type (see Appendix 1) on concordance between the practitioners' and empirical scientific estimates, so vegetation communities were treated as independent. The pairs of estimates, i.e., empirical and practitioners' estimates, were made within the same vegetation community; both represented integrated condition estimates, so protected area or practitioner was the unit of replication. All empirical estimates were conducted by the same author (C. N. Cook), eliminating interobserver variability and providing, at a minimum, a relative measure of condition to verify the accuracy of the practitioners' estimates.

Within each protected area, between 4 and 8 quadrats were randomly distributed across the vegetation type $(n=28)$ selected for candidate assessment (Appendix 1), with the number sampled being proportional to the area and heterogeneity of the vegetation (Gibbons et al. 2005). The overall condition score for the vegetation type sampled was the average of the condition metric scores for all quadrats.

Agreement between practitioners and rapid condition assessment Both the empirical condition assessment, i.e., BioMetric, and the practitioners' estimates, i.e., LEK, related to the structure, function, and composition of the vegetation, and both scored condition on a 4-point, ordinal scale (Table 1). Both estimates were made during the same 3-month period in 2007 . We subtracted the pairs of condition estimates, i.e., quantitative versus practitioners' estimates, to generate the difference score (range: -3 to +3 ) for each of the 28 protected areas. The difference score was influenced by whether the deviance between the two estimates was negative or positive. We corrected for this by using the absolute difference for subsequent analyses.

The data were assessed visually for normality and heteroscedasticity and found to conform to the assumptions of linear models, except where otherwise stated. Analysis of variance (ANOVA) was used to examine whether the absolute difference score, i.e., dependent variable, could be explained by the supporting information used, i.e., experience alone versus experience and data; the level of education of the practitioner; or their gender. We used linear regression to investigate the 
Fig. 2. The condition estimate for each vegetation type sampled. The circles represent the mean empirical condition scores, with standard error bars. The dashed lines indicate the corresponding condition score provided by practitioners, while the areas of grey shading provide a rounding error of \pm 0.5 around the practitioners' visual estimates $(n=28)$.

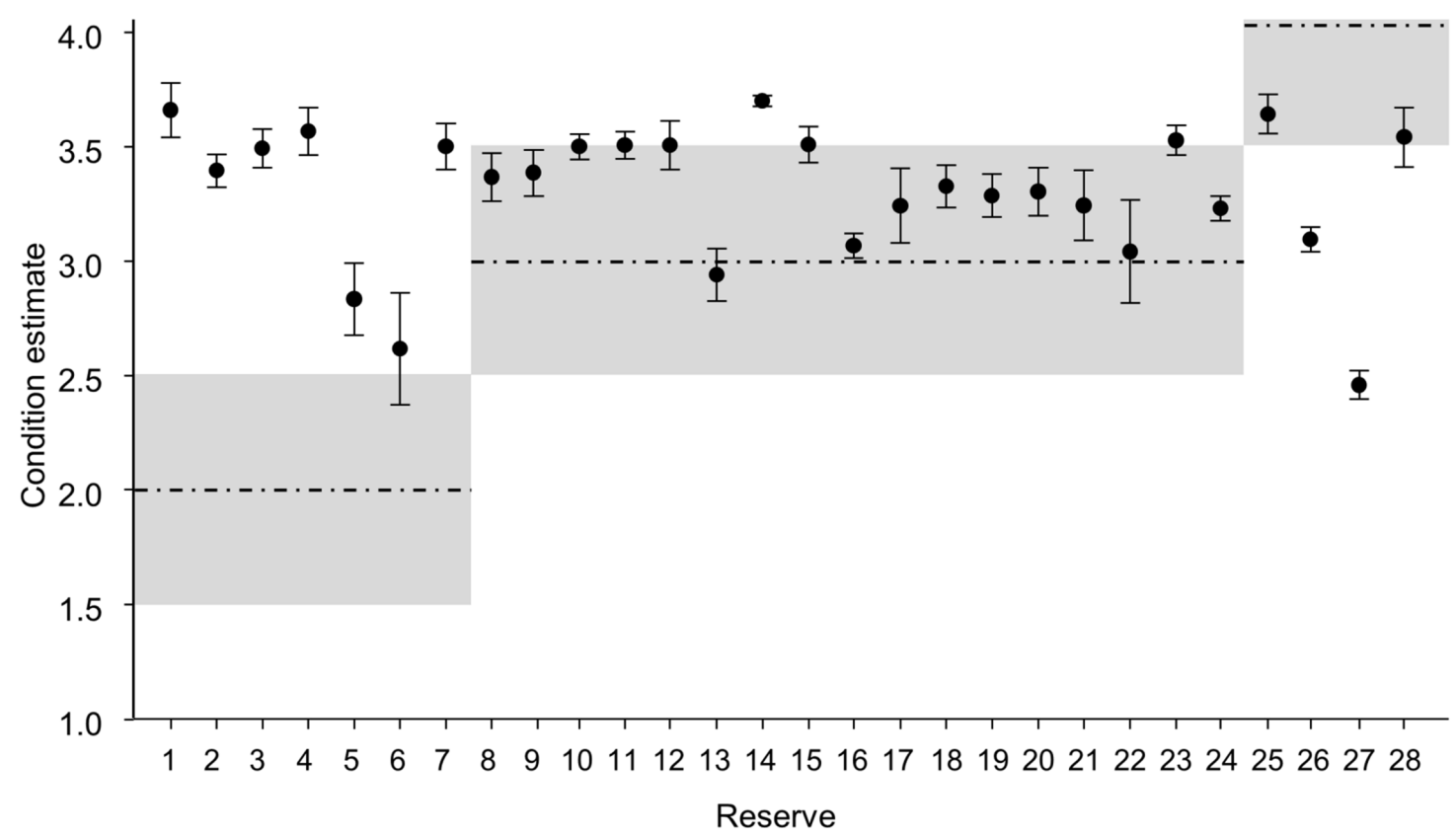

relationship between the absolute differences between the estimates, i.e., dependent variable, and a practitioner's level of experience, i.e., independent variable. We separately tested the number of years of experience a practitioner had with the protected area being sampled, i.e., $\log _{10}$ transformed, and their total years of experience as a protected area practitioner, i.e., square-root transformed.

\section{RESULTS}

Agreement between practitioners and rapid condition assessment The mean, i.e., absolute, difference score ( \pm standard error [SE]) between the empirical estimates and the practitioner's condition estimates was just over half a condition category $(\mu=0.6 \pm 0.09)$. We considered practitioners' assessments to match the empirical estimates when their condition estimates were within $1 \mathrm{SE}$ of the empirical estimate accounting for a rounding error of \pm 0.5 (Fig. 2). This level was chosen because deviations of even 1 condition rating equate to potentially large changes in condition, e.g., from "the components of the vegetation are not degraded" to "some components are degraded" (Table 1). Empirical estimates that straddled 2 visual condition assessment categories were excluded from this calculation $(n=7)$. Overall, $57 \%$ of practitioners were considered to provide comparable estimates, and a further $19 \%$ were within 1 assessment criteria of the empirical estimate. Male and female practitioners were equally likely to provide comparable estimates $\left(\mathrm{F}_{1,26}=0.12 ; \mathrm{p}=0.732\right)$.

Practitioners' estimates of condition were more likely to match the empirical scientific estimates when the vegetation was judged to be degraded but not currently at risk, i.e., condition score 3 (Table 1). We found a tendency for practitioners $(n=7)$ to be pessimistic about the condition of the vegetation, i.e., empirical estimates that occur above the gray shading (Fig. 2), particularly when vegetation was judged to be degraded and at risk, i.e., condition score 2 (Table 1 ). Practitioners at only 2 protected areas were optimistic about the condition of vegetation (Fig. 2).

Influence of supporting evidence on the accuracy of practitioners' judgments

We found no difference in whether practitioners' condition estimates matched the empirical scientific estimates when they reported having empirical data to support their judgment versus their personal experience alone $\left(\mathrm{F}_{1,26}=0.26 ; \mathrm{p}=0.617\right.$; Fig. 3). To verify this result, we contacted practitioners and obtained copies of the data sets used to support their assessments. We found that only 3 of 16 practitioners actually had condition data. The remaining practitioners had floristic surveys indicating the composition of the vegetation, but not the structural or functional components of condition. Adjusting for those who did not have empirical data about vegetation condition, the treatment groups became severely unbalanced, making the use of ANOVA undesirable. However, some of the practitioners with evidencebased information made estimates of vegetation condition that did not match the empirical scientific estimate, suggesting that data do not prevent some practitioners from building perceptions about their protected areas that are not supported by data. 
Fig. 3. The difference between the practitioner's (experiencebased) and the BioMetric (evidence-based) estimates of vegetation condition according to the type of information available to support the latter $(\mathrm{n}=28)$. Bars represent mean $( \pm$ S.E.).

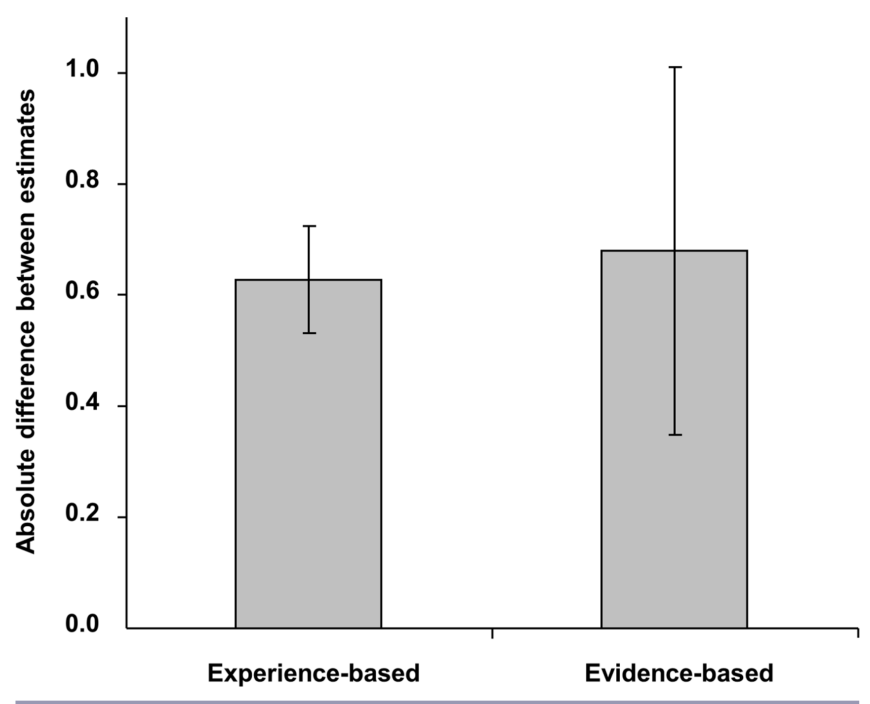

Influence of personal experience on the accuracy of practitioners' judgments

On average $( \pm S E)$, practitioners had $4.6 \pm 0.8$ years of experience managing their protected areas (range of 1-13 years) and 11.1 \pm 1.4 years of total management experience (range of $1-25$ years). We found no difference in comparability of practitioners' judgments according to the number of years of experience they had with the protected area assessed, i.e., $\log _{10}$ transformed $\left(\mathrm{R}^{2}\right.$ $=0.03 ; \beta=0.56$; degrees of freedom $=1,20 ; \mathrm{P}=0.428 ;$ Fig. $4 \mathrm{~A})$, or their total experience as protected area practitioners, i.e., square-root transformed $\left(\mathrm{R}^{2}=0.10 ; \beta=0.27\right.$; degrees of freedom $=1,20 ; \mathrm{P}=0.161$; Fig. 4B). We also found no effect of a practitioners' level of education on whether their estimates matched the empirical estimates of condition $\left(\mathrm{F}_{2,16}=0.75 ; \mathrm{p}=\right.$ $0.492)$; however, this sample was reduced to 18 practitioners because 10 declined to indicate their level of education. All of the remaining practitioners were highly educated, i.e., graduate diploma $(n=2)$, bachelor $(n=11)$, or postgraduate $(n=3)$ qualification.

\section{DISCUSSION}

\section{Practitioners' local ecological knowledge}

We found that almost $60 \%$ of practitioners made assessments of vegetation condition that matched the empirical scientific condition estimates. Including those practitioners within 1 assessment criteria of the empirical estimate, this figure increased to almost $80 \%$. This figure is despite most $(89 \%)$ practitioners having no data to assist their judgments, but rather relying on their personal observations generated through day-to-day management activities. Uncertainty exists in all estimates, including those generated through empirical assessment tools (see
Fig. 4. The relationship between a practitioners' experience and the accuracy of their condition estimate based on: (A) number of years with the protected area being assessed, and (B) the total number of years as a practitioner $(n=19)$. The solid line indicates the linear relationship between the points and the broken lines indicate confidence intervals for the regression line.
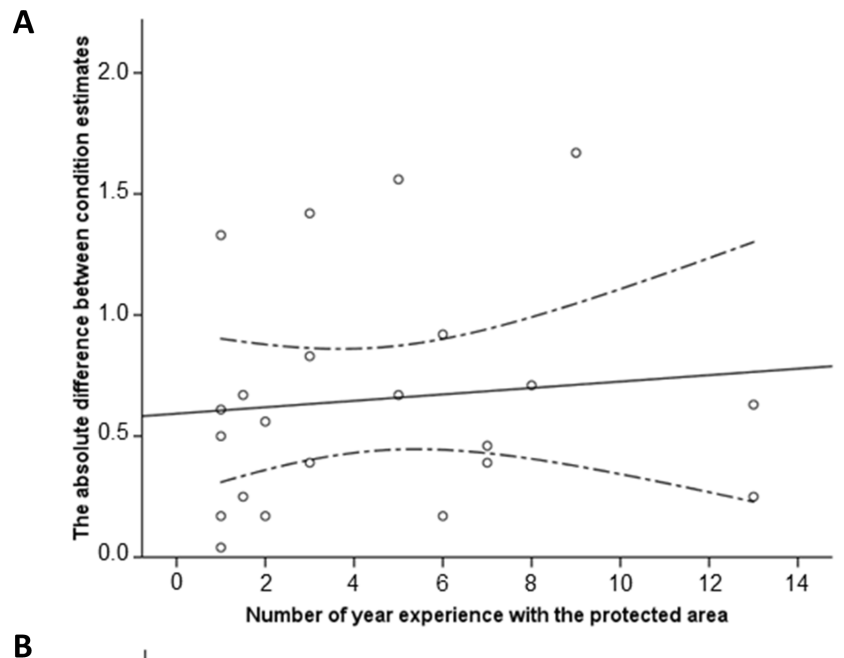

B

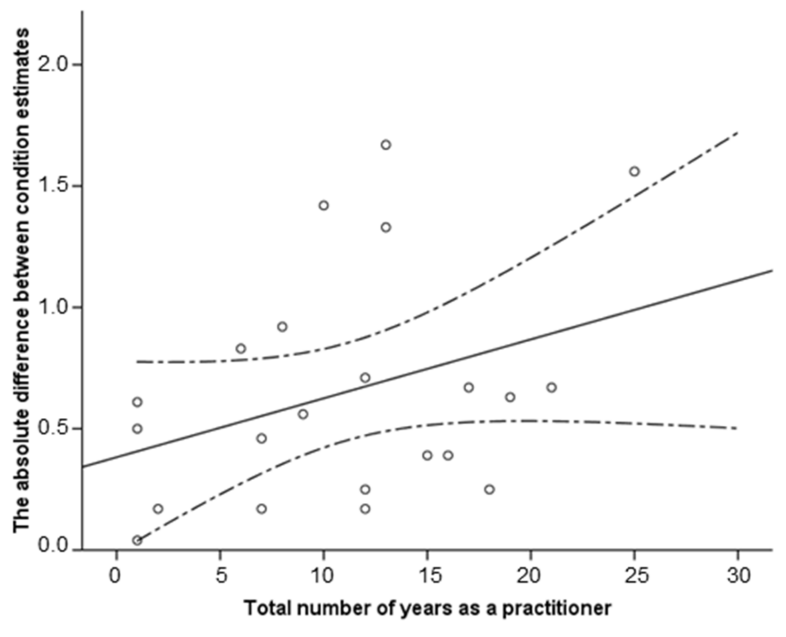

Gorrod and Keith 2009). Therefore, interpreting the value of practitioners' LEK as a source of information to guide management depends on the degree of confidence required from condition estimates. Inaccurate assessments of condition could lead to poor management decisions attributable to the premature cessation of vital management programs or by misdirecting management resources through a failure to recognize when programs are not needed. However, where subjective estimates of vegetation condition represent a good surrogate for empirical data, they provide a fast, cheap alternative to resource-intensive sampling techniques (Cook et al. 2010b). We found that estimates made by practitioners tended to be pessimistic relative to the empirical scientific estimates (Fig. 2), underestimating the condition of the vegetation. Employing the precautionary principle (UNEP 1993), conservative condition estimates that 
waste resources through unnecessary management actions are likely to be preferable to optimistic condition estimates that fail to protect biodiversity by prematurely terminating management actions. Therefore, $60-80 \%$ of practitioners should provide LEK that is a cost-effective alternative to rapid condition assessments or that results in no greater harm than a failure to recognize where restoration programs are no longer needed.

Practitioners' estimates most often matched the empirical estimates when condition was measured as moderately good (2.53.5; Fig. 2). However, the sample size for assessments at the extremes of the condition scale was small because few sites were estimated to be in very good condition and none to be in poor condition (Fig. 2). The under-representation of sites in very good or poor condition may be explained by the disturbance history of most of the sites leading to some degradation (Appendix 1). However, these sites are included in the protected area network because they retain important natural values (Dudley 2008). If it is easier for practitioners' to judge the condition of sites at the extremes of the condition spectrum, then our results may underestimate the value of practitioners' knowledge. Alternatively, if practitioners' estimates are less likely to match empirical estimates outside the midrange, this would raise concerns about the use of practitioners' judgments across the full spectrum of possible condition states. It is when vegetation is in poor condition that corrective action is most important for habitat restoration, and therefore it is important to assess practitioners' knowledge in these degraded sites. A larger study that assessed practitioners' estimates across the full condition spectrum would help build a broader understanding of the confidence that can be placed in practitioners' personal judgments of condition and when this information should be used to guide management decisions.

\section{Influences on the accuracy of local ecological knowledge}

High levels of agreement have been observed between LEK and empirical estimates of simple ecological attributes (Aswani and Lauer 2006, Anadón et al. 2009). We asked practitioners to judge a complex and multifaceted ecological attribute: vegetation condition (Keith and Gorrod 2006). Therefore, practitioners' LEK is likely to be stronger for more readily observable ecological attributes than we estimated, particularly for ecological attributes directly influenced by management actions such as fire suppression. Individuals learn more effectively when provided with feedback (Einhorn 1980, Shanteau 1992). Hence, observing the outcomes of direct interventions could be an important mechanism for providing practitioners' with the necessary feedback, leading to more closely comparable estimates. There is some evidence that practitioners can be highly accurate relative to empirical data when estimating the abundance of an actively managed invasive plant within their protected areas, even at very low abundances (Cook et al. 2014). More research is needed to determine whether practitioners are generally a good source of LEK for all aspects of management or whether their judgments are more robust for some ecological attributes or taxa than for others.

The reliability of LEK will vary if knowledge holders have an incentive to distort the information they provide (Anadón et al. 2009). Practitioners may have been concerned that reporting poorer estimates of condition would reflect badly on their job performance, which may have provided them with an incentive to inflate condition estimates. However, we found no support for this hypothesis, as practitioners' tended to be pessimistic about condition relative to the empirical condition estimates, underestimating the condition of vegetation (Fig. 2). Optimism and pessimism are aspects of personality (Marshall et al. 1992), so a tendency toward a pessimistic view of on-ground conditions may reflect the prevalence of a particular personality type of the practitioners. Conservation biology is believed to be dominated by a pessimistic outlook (Swaisgood and Sheppard 2010, Garnett and Lindenmayer 2011), and this pessimism may extend to the practitioners who conduct the day-to-day management of threats to biodiversity. It is accepted that not all individuals with LEK are equal in the substance and character of their knowledge (Davis and Wagner 2003), and that personal attributes may influence the reliability of LEK (Anadón et al. 2009). However, there is little or no information about the personal attributes necessary for individuals to be reliable sources of LEK. Our results suggest that the influence of an individual's personal outlook, such as tendency toward optimism or pessimism, should be investigated for its potential to influence the accuracy of LEK.

Building LEK is thought to require a "lengthy" period of regular or daily interaction with the environment or resource being assessed (Huntington 2000, Davis and Wagner 2003, Brook and McLachlan 2008, Davis and Ruddle 2010). However, the dearth of studies examining the accuracy of LEK means that little is known about how much experience is needed to generate accurate estimates. Ten years of experience has been shown to be sufficient for individuals to provide accurate estimates of species abundance (Anadón et al. 2009), but no studies demonstrate whether there is a minimum level of experience required. We found no relationship between the accuracy of condition estimates and the level of experience or education of practitioners, although the small sample size undoubtedly limits inference in this case. Likewise, there may be many other factors that we did not measure that may influence the LEK of practitioners. In addition to their education, practitioners also have access to a range of in-house training programs and mentoring by other staff members. Although these forms of training undoubtedly contribute to the knowledge of practitioners, they are more difficult to measure, and we did not assess them. We also did not record other factors that might influence the LEK of practitioners, such as whether they grew up in the local area or came from agricultural or other land management backgrounds, which may provide broader experience with the local environment. Practitioners' often seek multiple lines of evidence in building an understanding of the conditions in their reserves (Cook et al. 2012), and it is difficult to assess the degree to which different forms of evidence might have influenced their LEK. It is also possible that the level of experience required to build a strong understanding of vegetation condition varies with the type of vegetation being assessed or the personality of an individual. A great deal more work is needed to better understand the factors that contribute to practitioners building sound LEK. Future studies may benefit from conducting in-depth interviews with practitioners to investigate some of the other factors that may contribute to their LEK.

Practitioners are responsible for more than one protected area across their careers. Although a breadth of experience may be beneficial for building knowledge about the relative condition of 
protected areas, the shifting baseline syndrome (Pauly 1995) suggests that this movement between protected areas could interfere with practitioners' ability to build LEK that provides a solid foundation to judge change over time. Management agencies need to understand the relative costs and benefits of moving practitioners between protected areas in relation to the trade-off between gaining a diversity of experience and allowing practitioners to build a strong understanding of the local environment.

\section{CONCLUSION}

We suggest that the LEK of most practitioners provides a comparable, or slightly conservative, estimate of the condition of vegetation within their protected areas relative to empirical data. We provide an important first step in understanding practitioners' knowledge as a source of LEK, which shows that even when their judgments are based solely on day-to-day management experience, practitioners' estimates often correspond closely with commonly used empirical measures. However, there is still a considerable gap in our understanding about how individuals build LEK and the circumstances and personal attributes that contribute to building reliable knowledge for different ecological attributes. Given the potential value of such an abundant source of ecological information to guide protected area management, we encourage more research to help management agencies understand how to enable practitioners to build a strong understanding of the conditions in their reserves and to guide the use of this information for management decisions.

Responses to this article can be read online at: http://www.ecologyandsociety.org/issues/responses. $\mathrm{php} / 6341$

\section{Acknowledgments:}

This research was funded by the Australian Research Council, the NSW Office of Environment and Heritage, Parks Victoria, and the Commonwealth Director of National Parks. We thank the practitioners who participated in this study; S. Briggs for advice about adapting the BioMetric tool; and K. Wilson, T. Martin, D. Marshall, and M. McGeoch for valuable discussions and advice.

\section{LITERATURE CITED}

Agrawal, A. 1995. Dismantling the divide between indigenous and scientific knowledge. Development and Change 26:413-439.

Anadón, J. D., A. Giménez, R. Ballestar, and I. Pérez. 2009. Evaluation of local ecological knowledge as a method for collecting extensive data on animal abundance. Conservation Biology 23:617-625. http://dx.doi.org/10.1111/j.1523-1739.2008.01145. $\underline{\mathrm{x}}$

Aswani, S., and R. J. Hamilton. 2004. Integrating indigenous ecological knowledge and customary sea tenure with marine and social science for conservation of bumphead parrotfish (Bolbometopon muricatum) in the Roviana Lagoon, Solomon Islands. Environmental Conservation 31:69-83. http://dx.doi. org/10.1017/S037689290400116X
Aswani, S., and M. Lauer. 2006. Benthic mapping using local aerial photo interpretation and resident taxa inventories for designing marine protected areas. Environmental Conservation 33:263-273. http://dx.doi.org/10.1017/S0376892906003183

Berkes, F. 1999. Sacred ecology: traditional ecological knowledge and management systems. Taylor and Frances, Philadelphia, Pennsylvania, USA.

Berkes, F., J. Colding, and C. Folke. 2000. Rediscovery of traditional ecological knowledge as adaptive management. Ecological Applications 10:1251-1262. http://dx.doi.org/10.1890/1051-0761 (2000)010[1251:ROTEKA]2.0.CO;2

Brook, R. K., and S. M. McLachlan. 2008. Trends and prospects for local knowledge in ecological and conservation research and monitoring. Biodiversity and Conservation 17:3501-3512. http:// dx.doi.org/10.1007/s10531-008-9445-X

Burgman, M. A. 2001. Flaws in subjective assessments of ecological risks and means for correcting them. Australian Journal of Environmental Management 8:219-226. http://dx.doi. org/10.1080/14486563.2001.10648532

Burgman, M., A. Carr, L. Godden, R. Gregory, M. McBride, L. Flander, and L. Maguire. 2011. Redefining expertise and improving ecological judgment. Conservation Letters 4:81-87. http://dx.doi.org/10.1111/j.1755-263X.2011.00165.x

Cook, C. N. 2010. Validating management effectiveness assessments of protected areas in Australia. Dissertation. School of Integrative Systems, University of Queensland, Brisbane, Australia.

Cook, C. N., R. W. Carter, R. A. Fuller, and M. Hockings. 2012. Managers consider multiple lines of evidence important for biodiversity management decisions. Journal of Environmental Management 113:341-346. http://dx.doi.org/10.1016/j. jenvman.2012.09.002

Cook, C. N., R. W. Carter, and M. Hockings. 2014. Measuring the accuracy of management effectiveness evaluations of protected areas. Journal of Environmental Management 139:164-171. http://dx.doi.org/10.1016/j.jenvman.2014.02.023

Cook, C. N., and M. Hockings. 2011. Opportunities for improving the rigor of management effectiveness evaluations in protected areas. Conservation Letters 4:372-382. http://dx.doi.org/10.1111/ j.1755-263X.2011.00189.X

Cook, C. N., M. Hockings, and R. W. Carter. 2010a. Conservation in the dark? The information used to support management decisions. Frontiers in Ecology and the Environment 8:181-186. http://dx.doi.org/10.1890/090020

Cook, C. N., G. Wardell-Johnson, M. Keatley, S. A. Gowans, M. S. Gibson, M. E. Westbrooke, and D. J. Marshall. 2010b. Is what you see what you get? Visual vs. measured assessments of vegetation condition. Journal of Applied Ecology 47:650-661. http://dx.doi.org/10.1111/j.1365-2664.2010.01803.x

Davis, A., and K. Ruddle. 2010. Constructing confidence: rational skepticism and systematic enquiry in local ecological knowledge research. Ecological Applications 20:880-894. http://dx.doi. org/10.1890/09-0422.1 
Davis, A., and J. R. Wagner. 2003. Who knows? On the importance of identifying "experts" when researching local ecological knowledge. Human Ecology 31:463-489. http://dx.doi.org/10.1023/ A:1025075923297

Department of Environment and Conservation (DEC). 2006. New South Wales state of the environment 2006. DEC, Sydney, Australia.

Dudley, N. 2008. Guidelines for applying protected area management categories. International Union for Conservation of Nature, Gland, Switzerland.

Einhorn, H. J. 1980. Learning from experience and suboptimal rules for decision making. Pages 66-80 in T. S. Wallsten, editor. Cognitive processes in choice and decision behavior. Lawrence Erlbaum Associates, Hillsdale, New Jersey, USA.

Fazey, I., J. A. Fazey, and D. M. A. Fazey. 2005. Learning more effectively from experience. Ecology and Society 10(2): 4. [online] URL: http://www.ecologyandsociety.org/vol10/iss2/art4/

Gadgil, M., F. Berkes, and C. Folke. 1993. Indigenous knowledge for biodiversity conservation. Ambio 22:151-156.

Garnett, S. T., and D. B. Lindenmayer. 2011. Conservation science must engender hope to succeed. Trends in Ecology \& Evolution 26:59-60. http://dx.doi.org/10.1016/j.tree.2010.11.009

Gibbons, P., D. Ayers, J. Seddon, S. Doyle, and S. Briggs. 2005. BioMetric Version 1.8: a terrestrial biodiversity assessment tool for the NSW property vegetation plan developer. Operational manual. NSW Department of Environment and Conservation, Hurstville, Australia.

Gibbons, P., S. V. Briggs, D. A. Ayers, S. Doyle, J. Seddon, C. McElhinny, N. Jones, R. Sims, and J. S. Doody. 2008. Rapidly quantifying reference conditions in modified landscapes. Biological Conservation 141:2483-2493. http://dx.doi.org/10.1016/ j.biocon.2008.07.009

Gibbons, P., S. V. Briggs, D. Ayers, J. Seddon, S. Doyle, P. Cosier, C. McElhinny, V. Pelly, and K. Roberts. 2009. An operational method to assess impacts of land clearing on terrestrial biodiversity. Ecological Indicators 9:26-40. http://dx.doi. org/10.1016/j.ecolind.2008.01.006

Gibbons, P., and D. Freudenberger. 2006. An overview of methods used to assess vegetation condition at the scale of the site. Ecological Management \& Restoration 7:S10-S17. http://dx.doi. org/10.1111/j.1442-8903.2006.00286.x

Gilchrist, G., M. Mallory, and F. Merkel. 2005. Can local ecological knowledge contribute to wildlife management? Case studies of migratory birds. Ecology and Society 10(1): 20. [online] URL: http://www.ecologyandsociety.org/vol10/iss1/art20/

Gorrod, E. J., and D. A. Keith. 2009. Observer variation in field assessments of vegetation condition: implications for biodiversity conservation. Ecological Management \& Restoration 10:31-40. http://dx.doi.org/10.1111/j.1442-8903.2009.00437.x

Hernandez-Stefanoni, J. L., J. B. Pineda, and G. Valdes-Valadez. 2006. Comparing the use of indigenous knowledge with classification and ordination techniques for assessing the species composition and structure of vegetation in a tropical forest.
Environmental Management 37:686-702. http://dx.doi.org/10.1007/ s00267-004-0371-8

Hockings, M., C. N. Cook, R. W. Carter, and R. James. 2009. Accountability, reporting, or management improvement? Development of a State of the Parks assessment system in New South Wales, Australia. Environmental Management 43:1013-1025. http://dx.doi.org/10.1007/s00267-009-9277-9

Huntington, H. P. 2000. Using traditional ecological knowledge in science: methods and applications. Ecological Applications 10:1270-1274. http://dx.doi.org/10.1890/1051-0761(2000)010[1270: UTEKIS]2.0.CO;2

International Union for Conservation of Nature (IUCN). 1994. Guidelines for protected area management categories. IUCN, The World Conservation Union Commission on National Parks and Protected Areas with the assistance of the World Conservation Monitoring Centre, Gland, Switzerland, and Cambridge, UK.

Keith, D., and E. Gorrod. 2006. The meanings of vegetation condition. Ecological Management \& Restoration 7:S7-S9. http:// dx.doi.org/10.1111/j.1442-8903.2006.00285.x

Kuhnert, P. M., T. G. Martin, and S. P. Griffiths. 2010. A guide to eliciting and using expert knowledge in Bayesian ecological models. Ecology Letters 13:900-914. http://dx.doi.org/10.1111/ j.1461-0248.2010.01477.X

Lauer, M., and S. Aswani. 2008. Integrating indigenous ecological knowledge and multi-spectral image classification for marine habitat mapping in Oceania. Ocean \& Coastal Management 51:495-504. http://dx.doi.org/10.1016/j.ocecoaman.2008.04.006

Lauer, M., and S. Aswani. 2009. Indigenous ecological knowledge as situated practices: understanding fishers' knowledge in the western Solomon Islands. American Anthropologist 111:317-329. http://dx.doi.org/10.1111/j.1548-1433.2009.01135.x

Leedy, D. L. 1949. Ohio pheasant nesting surveys based on farmer interviews. Journal of Wildlife Management 13:274-286. http://dx. doi.org/10.2307/3795869

Lele, S. R., and K. L. Allen. 2006. On using expert opinion in ecological analyses: a frequentist approach. Environmetrics 17:683-704. http://dx.doi.org/10.1002/env.786

Lozano-Montes, H. M., T. J. Pitcher, and N. Haggan. 2008. Shifting environmental and cognitive baselines in the upper Gulf of California. Frontiers in Ecology and the Environment 6:75-80. http://dx.doi.org/10.1890/070056

Marshall, G. N., C. B. Wortman, J. W. Kusulas, L. K. Hervig, and R. R. Vickers, Jr. 1992. Distinguishing optimism from pessimism: relations to fundamental dimensions of mood and personality. Journal of Personality and Social Psychology 62:1067-1074. http:// dx.doi.org/10.1037/0022-3514.62.6.1067

Martin, T. G., M. A. Burgman, F. Fidler, P. M. Kuhnert, S. LowChoy, M. McBride, and K. Mengersen. 2012. Eliciting expert knowledge in conservation science. Conservation Biology 26:29-38. http://dx.doi.org/10.1111/j.1523-1739.2011.01806.x

McGregor, D. 2000. The state of traditional ecological knowledge research in Canada: a critique of current theory and practice. Pages 436-458 in R. Laliberte, P. Sette, J. Waldram, R. Innes, B. 
Macdougall, L. McBain, and F. Barron, editors. Expressions in Canadian native studies. University of Saskatchewan Extension Press, Saskatoon, Canada.

Moller, H., F. Berkes, P. O. Lyver, and M. Kislalioglu. 2004. Combining science and traditional ecological knowledge: monitoring populations for co-management. Ecology and Society

9(3): 2. [online] URL: http://www.ecologyandsociety.org/vol9/ iss $3 / \operatorname{art} 21$

Pauly, D. 1995. Anecdotes and the shifting baseline syndrome of fisheries. Trends in Ecology \& Evolution 10:430. http://dx.doi. org/10.1016/S0169-5347(00)89171-5

Plous, S. 1993. The psychology of judgment and decision making. McGraw-Hill, New York, New York, USA.

Shanteau, J. 1992. The psychology of experts an alternative view. Pages 11-23 in G. Wright and F. Bolger, editors. Expertise and decision support. Plenum, New York, New York, USA. http://dx. doi.org/10.1007/978-0-585-34290-0 2

Stave, J., G. Oba, I. Nordal, and N. C. Stenseth. 2007. Traditional ecological knowledge of a riverine forest in Turkana, Kenya: implications for research and management. Biodiversity and Conservation 16:1471-1489. http://dx.doi.org/10.1007/s10531-006-9016y

Sutherland, W. J. 2006. Predicting the ecological consequences of environmental change: a review of the methods. Journal of Applied Ecology 43:599-616. http://dx.doi.org/10.1111/ j.1365-2664.2006.01182.x

Sutherland, W. J., A. S. Pullin, P. M. Dolman, and T. M. Knight. 2004. The need for evidence-based conservation. Trends in Ecology \& Evolution 19:305-308. http://dx.doi.org/10.1016/j. $\underline{\text { tree.2004.03.018 }}$

Swaisgood, R. R., and J. K. Sheppard. 2010. The culture of conservation biologists: show me the hope! BioScience 60:626-630. http://dx.doi.org/10.1525/bio.2010.60.8.8

United Nations Environment Program (UNEP). 1993. The Convention on Biological Diversity. Secretariat of the Convention on Biological Diversity, Rio de Janiero, Brazil.

Vaughan, N., E. A. Lucas, S. Harris, and P. C. L. White. 2003. Habitat associations of European hares Lepus europaeus in England and Wales: implications for farmland management. Journal of Applied Ecology 40:163-175. http://dx.doi.org/10.1046/ j.1365-2664.2003.00784.x

Woodwell, G. M. 1989. On causes of biotic impoverishment. Ecology 70:14-15. 


\section{Appendix 1.}

Table A1.1 Description of each vegetation type sampled and the disturbance and management history.

\begin{tabular}{|c|c|c|c|}
\hline Vegetation type & $\begin{array}{l}\text { No. } \\
\text { quadrats }\end{array}$ & Description & Disturbance history \\
\hline $\begin{array}{l}\text { Apple Box - Norton's } \\
\text { Box - Red } \\
\text { Stringybark moist } \\
\text { grassy tall open forest }\end{array}$ & 6 & $\begin{array}{l}\text { Canopy dominated by Eucalyptus bridgesiana, } \\
\text { E. nortonii and E. macrorhyncha. Mid-storey } \\
\text { species include Acacia dealbata, Bursaria } \\
\text { spinosa and Exocarpos cupressiformis. Ground } \\
\text { cover species include Microlaena stipoides, } \\
\text { Dichondra repens and Senecio sp. }\end{array}$ & Grazing \\
\hline $\begin{array}{l}\text { Black Booyong - } \\
\text { Rosewood - Yellow } \\
\text { Carabeen subtropical } \\
\text { rainforest }\end{array}$ & 5 & $\begin{array}{l}\text { Canopy species include Dysoxylum } \\
\text { fraserianum and Heritiera actinophylla. Mid- } \\
\text { storey species include Neolitsea sp. and } \\
\text { Capparis arborea. Ground cover includes } \\
\text { Adiantum formosum and Pteris umbrosa }\end{array}$ & Habitat fragmentation \\
\hline $\begin{array}{l}\text { Black Sallee grassy } \\
\text { woodland }\end{array}$ & 5 & $\begin{array}{l}\text { Canopy dominated by Eucalyptus stellulata } \\
\text { and E. pauciflora. Grassy understorey } \\
\text { dominated by Poa sieberiana and } P \text {. } \\
\text { labillardierei }\end{array}$ & $\begin{array}{l}\text { Grazing, timber } \\
\text { harvesting, and pollution }\end{array}$ \\
\hline $\begin{array}{l}\text { Blakely's Red Gum - } \\
\text { Yellow Box grassy } \\
\text { woodland }\end{array}$ & 5 & $\begin{array}{l}\text { Canopy dominated by Eucalyptus blakelyi and } \\
\text { E. melliodora. Mid-storey dominated by Acacia } \\
\text { dealbata. Ground cover species include } \\
\text { Themeda australis, Poa sieberiana and } \\
\text { Bothriochloa macra }\end{array}$ & Grazing \\
\hline $\begin{array}{l}\text { Blue-leaved } \\
\text { Stringybark shrubby } \\
\text { open forest }\end{array}$ & 4 & $\begin{array}{l}\text { Canopy dominated by Eucalyptus agglomerata. } \\
\text { Mid-storey species include Acacia sp, } \\
\text { Monotoca scoparia and Podolobium } \\
\text { ilicifolium. Ground cover species include } \\
\text { Joycea pallida, Caustis flexuosa and Lomandra } \\
\text { longifolia }\end{array}$ & Timber harvesting \\
\hline $\begin{array}{l}\text { Brittle Gum - } \\
\text { peppermint open } \\
\text { forest }\end{array}$ & 6 & $\begin{array}{l}\text { Canopy dominated by Eucalyptus mannifera } \\
\text { and E. dives. Mid-storey species include } \\
\text { Hibbertia obtusifolia, Monotoca scoparia and } \\
\text { Platylobium formosum. Ground cover species } \\
\text { include Senecio tenuiflorus, Joycea pallid and } \\
\text { Gonocarpus tetragynus }\end{array}$ & $\begin{array}{l}\text { Grazing and timber } \\
\text { harvesting }\end{array}$ \\
\hline $\begin{array}{l}\text { Broad-leaved } \\
\text { Ironbark - Melaleuca } \\
\text { decora shrubby open } \\
\text { forest }\end{array}$ & 5 & $\begin{array}{l}\text { Canopy dominated by Eucalyptus fibrosa. Mid- } \\
\text { storey species include Lissanthe strigosa, } \\
\text { Melaleuca nodosa and Daviesia ulicifolia. } \\
\text { Ground cover includes Entolasia stricta, } \\
\text { Microlaena stipoides and Cheilanthes sieberi }\end{array}$ & $\begin{array}{l}\text { Altered water regimes } \\
\text { and pollution }\end{array}$ \\
\hline
\end{tabular}


Table A1.1 Continued

\begin{tabular}{|c|c|c|c|}
\hline Vegetation type & $\begin{array}{c}\text { No. } \\
\text { quadrats }\end{array}$ & Description & Disturbance history \\
\hline $\begin{array}{l}\text { Broad-leaved } \\
\text { Peppermint - Norton's } \\
\text { Box - Red } \\
\text { Stringybark tall open } \\
\text { forest }\end{array}$ & 5 & $\begin{array}{l}\text { Canopy dominated by Eucalyptus dives, E. } \\
\text { nortonii and E. macrorhyncha. Mid-storey } \\
\text { species include Acacia dealbata, Cassinia } \\
\text { aculeata and Hibbertia sp. Ground cover } \\
\text { species include Poa sieberiana, Lomandra } \\
\text { filiformis and Joycea pallida }\end{array}$ & Grazing \\
\hline $\begin{array}{l}\text { Broad-leaved } \\
\text { Stringybark - } \\
\text { Blakely's Red Gum } \\
\text { grassy woodlands }\end{array}$ & 8 & $\begin{array}{l}\text { Canopy dominated by Eucalyptus caliginosa } \\
\text { and E. blakelyi. Grassy understorey dominated } \\
\text { by Poa sieberiana and Themeda australis }\end{array}$ & Timber harvesting \\
\hline $\begin{array}{l}\text { Dwyer's Red Gum - } \\
\text { Black Cypress Pine - } \\
\text { Currawang woodland }\end{array}$ & 6 & $\begin{array}{l}\text { Canopy dominated by Eucalyptus dwyeri, } \\
\text { Callitris endlicheri and Acacia doratoxylon. } \\
\text { Mid-storey species include Cassinia laevis, } \\
\text { Grevillea floribunda, Acacia sp. Ground cover } \\
\text { species include Gonocarpus elatus, } \\
\text { Lepidosperma laterale and Austrostipa sp. }\end{array}$ & $\begin{array}{l}\text { Grazing and timber } \\
\text { harvesting }\end{array}$ \\
\hline $\begin{array}{l}\text { Forest Red Gum - } \\
\text { Rough-barked Apple } \\
\text { - White Stringybark } \\
\text { grassy woodlands }\end{array}$ & 5 & $\begin{array}{l}\text { Canopy dominated by Eucalyptus tereticornis, } \\
\text { Angophora floribunda and E. globoidea. Mid- } \\
\text { storey of Acacia mearnsii, Bursaria spinosa } \\
\text { and Ozothamnus diosmifolius. Ground cover } \\
\text { species include Themeda australis, } \\
\text { Notodanthonia racemosa and Dichanthium } \\
\text { sericeum }\end{array}$ & $\begin{array}{l}\text { Grazing, timber } \\
\text { harvesting and mining }\end{array}$ \\
\hline $\begin{array}{l}\text { Giant Stinging Tree - } \\
\text { Fig dry subtropical } \\
\text { rainforest }\end{array}$ & 6 & $\begin{array}{l}\text { Canopy dominated by Dendrocnide excelsa and } \\
\text { Ficus sp. Mid-storey species include } \\
\text { Eupomatia laurina and Pittosporum } \\
\text { multiflorum. Ground cover species include } \\
\text { Adiantum formosum and Pellaea falcate }\end{array}$ & $\begin{array}{l}\text { Inappropriate fire } \\
\text { regimes }\end{array}$ \\
\hline $\begin{array}{l}\text { Grey Box - Forest } \\
\text { Red Gum - Grey } \\
\text { Ironbark open forest }\end{array}$ & 6 & $\begin{array}{l}\text { Canopy dominated by Eucalyptus siderophloia, } \\
\text { E. tereticornis and E. propinqua. Mid-storey of } \\
\text { Allocasuarina torulosa. Ground cover species } \\
\text { include Themeda australis, Desmodium } \\
\text { varians, and Dichondra repens }\end{array}$ & $\begin{array}{l}\text { Grazing and timber } \\
\text { harvesting }\end{array}$ \\
\hline $\begin{array}{l}\text { Grey Gum - Narrow- } \\
\text { leaved Stringybark - } \\
\text { ironbark woodland }\end{array}$ & 7 & $\begin{array}{l}\text { Canopy species include Eucalyptus punctata, } \\
\text { E. sparsifolia and E. crebra. Mid-storey species } \\
\text { include Acacia sp., Persoonia linearis and } \\
\text { Leucopogon muticus. Ground cover species } \\
\text { include Lomandra glauca and Cleistochloa } \\
\text { rigida }\end{array}$ & $\begin{array}{l}\text { Grazing and } \\
\text { inappropriate fire } \\
\text { regimes }\end{array}$ \\
\hline $\begin{array}{l}\text { Hoop Pine - Yellow } \\
\text { Tulipwood dry } \\
\text { rainforest }\end{array}$ & 5 & $\begin{array}{l}\text { Canopy dominated by Araucaria cunninghamii } \\
\text { and Backhousia sciadophora. Mid-storey } \\
\text { species include Capparis arborea and } \\
\text { Citriobatus pauciflorus. Ground cover species } \\
\text { include Doodia aspera and Pellaea falcate }\end{array}$ & Timber harvesting \\
\hline
\end{tabular}


Table A1.1 Continued

11

\begin{tabular}{|c|c|c|c|}
\hline Vegetation type & $\begin{array}{c}\text { No. } \\
\text { quadrats }\end{array}$ & Description & Disturbance history \\
\hline Mangrove forest & 6 & $\begin{array}{l}\text { Canopy of Avicennia marina and Aegiceras } \\
\text { corniculatum. Ground cover dominated by } \\
\text { Sarcocornia quinqueflora }\end{array}$ & Grazing \\
\hline $\begin{array}{l}\text { Mountain Ribbon } \\
\text { Gum - Messmate } \\
\text { open forest }\end{array}$ & 7 & $\begin{array}{l}\text { Canopy dominated by Eucalyptus nobilis and } \\
\text { E. obliqua. Mid-storey dominated by } \\
\text { Leucopogon lanceolatus, Podolobium } \\
\text { ilicifolium, Acacia sp. Ground cover species } \\
\text { include Lomandra longifolia, Pteridium } \\
\text { esculentum and Poa sieberiana }\end{array}$ & $\begin{array}{l}\text { Timber harvesting and } \\
\text { mining }\end{array}$ \\
\hline $\begin{array}{l}\text { Mugga Ironbark - } \\
\text { Red Stringybark - } \\
\text { Long-leaved Box dry } \\
\text { grass forest }\end{array}$ & 6 & $\begin{array}{l}\text { Canopy species include Eucalyptus } \\
\text { macrorhyncha, E. rossii and E. goniocalyx. } \\
\text { Mid-storey dominated by Allocasuarina } \\
\text { verticillata and Callitris sp. Ground cover } \\
\text { species include Cheilanthes sieberi, } \\
\text { Gonocarpus tetragynus and Daucus } \\
\text { glochidiatus }\end{array}$ & Grazing and mining \\
\hline $\begin{array}{l}\text { New England } \\
\text { Blackbutt - } \\
\text { Tallowwood grassy } \\
\text { forest }\end{array}$ & 7 & $\begin{array}{l}\text { Overstorey dominated by Eucalyptus } \\
\text { campanulata and E. microcorys. Mid-storey } \\
\text { dominated by Allocasuarina torulosa and } \\
\text { Leucopogon lanceolatus. Ground cover } \\
\text { includes Hibbertia scandens, Pteridium } \\
\text { esculentum and grasses such as Poa sieberiana } \\
\text { and Imperata cylindrica }\end{array}$ & $\begin{array}{l}\text { Grazing, inappropriate } \\
\text { fire regimes and timber } \\
\text { harvesting }\end{array}$ \\
\hline $\begin{array}{l}\text { Phragmites australis } \\
\text { and Typha orientalis } \\
\text { coastal freshwater } \\
\text { wetlands }\end{array}$ & 8 & $\begin{array}{l}\text { Freshwater wetland community dominated by } \\
\text { Phragmites australis, Typha orientalis and a } \\
\text { wide variety of sedge and rush species } \\
\text { including Elaeocharis sphacelata, Ludwigia } \\
\text { peploides, Triglochin procera and Juncus } \\
\text { usitatus }\end{array}$ & $\begin{array}{l}\text { Altered water regimes, } \\
\text { grazing and timber } \\
\text { harvesting }\end{array}$ \\
\hline $\begin{array}{l}\text { Red Bloodwood - } \\
\text { Blackbutt - Spotted } \\
\text { Gum shrubby open } \\
\text { forest }\end{array}$ & 6 & $\begin{array}{l}\text { Canopy dominated by Corymbia gummifera, C. } \\
\text { maculata and Eucalyptus pilularis. Mid-storey } \\
\text { species include Allocasuarina littoralis, } \\
\text { Pimelea linifolia and Banksia spinulosa. } \\
\text { Ground cover species include Entolasia stricta, } \\
\text { Lomandra longifolia and Dianella caerulea }\end{array}$ & Timber harvesting \\
\hline $\begin{array}{l}\text { Red Bloodwood - } \\
\text { Hard-leaved Scribbly } \\
\text { Gum - Silvertop Ash } \\
\text { heathy open forest }\end{array}$ & 5 & $\begin{array}{l}\text { Canopy dominated by Corymbia gummifera } \\
\text { and Eucalyptus sclerophylla. Mid-storey } \\
\text { species include Lambertia formosa, Persoonia } \\
\text { levis and Banksia spinulosa. Ground cover } \\
\text { species include Lomandra obliqua, Patersonia } \\
\text { sericea, and Entolasia stricta }\end{array}$ & $\begin{array}{l}\text { Inappropriate fire } \\
\text { regimes }\end{array}$ \\
\hline
\end{tabular}


Table A1.1 Continued

\begin{tabular}{|c|c|c|c|}
\hline Vegetation type & $\begin{array}{l}\text { No. } \\
\text { quadrats }\end{array}$ & Description & Disturbance history \\
\hline \multirow{2}{*}{$\begin{array}{l}\text { Red Bloodwood - } \\
\text { scribbly gum heathy } \\
\text { woodland }\end{array}$} & 7 & $\begin{array}{l}\text { Canopy dominated by Corymbia gummifera } \\
\text { and Eucalyptus haemastoma }\end{array}$ & \multirow[t]{2}{*}{ Land clearing } \\
\hline & & $\begin{array}{l}\text { Mid-storey species include Leptospermum } \\
\text { trinervium, Lambertia formosa and Persoonia } \\
\text { levis. Ground cover species include Caustis } \\
\text { flexuosa, Lomandra sp. and Dampiera stricta }\end{array}$ & \\
\hline $\begin{array}{l}\text { Red Box - Long- } \\
\text { leaved Box - Red } \\
\text { Stringybark sheltered } \\
\text { open forest }\end{array}$ & 6 & $\begin{array}{l}\text { Canopy dominated by Eucalyptus goniocalyx, } \\
\text { E. polyanthemos and E. macrorhyncha. Mid- } \\
\text { storey species include Brachyloma daphnoides, } \\
\text { Acacia paradoxa and Persoonia sericea. } \\
\text { Ground cover species include Joycea pallida, } \\
\text { Poa sieberiana and Gonocarpus tetragynus }\end{array}$ & $\begin{array}{l}\text { Grazing, mining and } \\
\text { timber harvesting }\end{array}$ \\
\hline $\begin{array}{l}\text { Red Stringybark } \\
\text { woodland }\end{array}$ & 7 & $\begin{array}{l}\text { Canopy dominated by Eucalyptus } \\
\text { macrorhyncha and E. polyanthemos. Mid- } \\
\text { storey species include Hibbertia obtusifolia and } \\
\text { Macrozamia secunda. Ground cover species } \\
\text { include Lomandra sp., Lepidosperma laterale } \\
\text { and Patersonia sericea }\end{array}$ & Mining \\
\hline $\begin{array}{l}\text { River Red Gum - } \\
\text { herbaceous tall open } \\
\text { forest }\end{array}$ & 5 & $\begin{array}{l}\text { Canopy dominated by Eucalyptus } \\
\text { camaldulensis. Mid-storey dominated by } \\
\text { Acacia stenophylla. Ground cover species } \\
\text { include Paspalidium jubiflorum, Wahlenbergia } \\
\text { fluminalis and Senecio quadridentatus }\end{array}$ & $\begin{array}{l}\text { Altered water regimes, } \\
\text { grazing and timber } \\
\text { harvesting }\end{array}$ \\
\hline $\begin{array}{l}\text { Spotted Gum - Grey } \\
\text { Ironbark open forest }\end{array}$ & 7 & $\begin{array}{l}\text { Canopy dominated by Corymbia maculata and } \\
\text { Eucalyptus siderophloia, and E. punctata. } \\
\text { Midstorey dominated by Breynia oblongifolia. } \\
\text { Ground cover species include Imperata } \\
\text { cylindrical, Entolasia stricta and Themeda } \\
\text { australis }\end{array}$ & $\begin{array}{l}\text { Grazing and timber } \\
\text { harvesting }\end{array}$ \\
\hline $\begin{array}{l}\text { White Box - Red } \\
\text { Stringybark shrubby } \\
\text { woodlands }\end{array}$ & 4 & $\begin{array}{l}\text { Canopy dominated by Eucalyptus albens and E. } \\
\text { macrorhyncha. Mid-stroey species include } \\
\text { Olearia elliptica, Notelaea microcarpa and } \\
\text { Cassinia quinquefaria. Ground cover species } \\
\text { include Oplismenus aemulus, Gahnia aspera } \\
\text { and Desmodium brachypodum }\end{array}$ & $\begin{array}{l}\text { Grazing and timber } \\
\text { harvesting }\end{array}$ \\
\hline
\end{tabular}

